\title{
Letter to the Editor: Cemented versus uncemented hemiarthroplasty for femoral neck fractures in patients with neuromuscular diseases: a minimum of 2 years' follow-up study
}

\author{
Wang Xing, Huang Qiang ${ }^{*}$ and Pei Fuxing
}

\section{Dear Editor,}

Recently, I read with great interest the study entitled "Cemented versus uncemented hemiarthroplasty for femoral neck fractures in patients with neuromuscular diseases: a minimum of 2 years' follow-up study" by Wang et al. [1] The following concerns need to be explained cautiously.

First, authors did not mention the time points and frequency of pain evaluation. The same problem existed with Harris hip score (HHS). Authors found the intraoperative blood loss were less in the uncemented group. However, they did not mention how was intraoperative blood loss medical calculated? Furthermore, authors reported that although the between-group difference was not statistically significant, they found that the uncemented group was associated with higher risk of postoperative periprosthetic fracture. In addition to bone density, periprosthetic fractures are generally related to either inexperienced surgeons or inadequate surgical technique. However, they did not mention were all surgeries performed by same surgeon with standard procedure? If there is a difference between the two groups, it will have a certain impact on the effect of surgery and complications.

Second, the authors concluded that intraoperative death almost exclusively occurred during cemented

\footnotetext{
* Correspondence: huangqiang4325@126.com

The work was performed in Department of Orthopaedic Surgery, West China Hospital, Sichuan University.

Department of Orthopaedic Surgery, West China Hospital, Sichuan University, No. 37, Guoxue Road, Wuhou district, Chengdu 610041, Sichuan, People's Republic of China
}

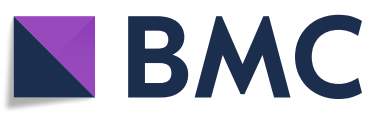

procedures, which may be caused by the Bone cement implantation syndrome (BCIS), but no intraoperative death was found in this study, which showed that the use of cement has no detrimental effect on the shortand mid-term mortality in patients with neuromuscular diseases. However, BCIS is rare, and so historically controlled comparative studies are difficult, because the infrequency of the event makes it hard to compare risk factors relevant to the condition. However, large national databases have given us populations to perform reliable statistical analyses [2]. In a study of more than 11,000 patients with hip fracture, they found use of cement to be independently associated with an increased risk of death on the day of surgery and the following day. When ASA increased from 1 or 2 to 3 or 4, the number needed to harm (to cause 1 death from cementation) rose from 1 of 811 patients to 1 of 33 operated patients [2]. About $60 \%$ of these early fatalities were directly attributed to bone cement [3]. Thus, the key to avoiding cementrelated deaths during or soon after hemiarthroplasty surgery for hip fracture is for the surgeon to choose an uncemented implant.

\section{Abbreviations \\ VAS: Visual analog scale; HHS: Harris hip score; BCIS: Bone cement implantation syndrome; ASA: American Society of Anesthesiologists}

\section{Acknowledgements \\ Not applicable.}

Authors' contributions

WX drafted the manuscript. HQ and FX (Pei) revised it. The authors read and approved the final manuscript. 


\section{Funding}

The authors received no financial support for the research and/or authorship of this article.

\section{Availability of data and materials}

Not applicable.

\section{Declarations}

Ethics approval and consent to participate

Not applicable.

\section{Consent for publication}

Not applicable.

\section{Competing interests}

The authors declare that they have no competing interests.

Received: 23 July 2021 Accepted: 26 July 2021

Published online: 20 August 2021

\section{References}

1. Wang Y, Wang Z, Tian S, et al. Cemented versus uncemented hemiarthroplasty for femoral neck fractures in patients with neuromuscular diseases: a minimum of 2 years' follow-up study. J Orthop Surg Res. 2021; 16(1):418.

2. Talsnes $\mathrm{O}$, Vinje $\mathrm{T}$, Gjertsen JE, et al. Perioperative mortality in hip fracture patients treated with cemented and uncemented hemiprosthesis: a register study of 11,210 patients. Int Orthop. 2013;37(6):1135-40.

3. Pripp $A H$, Talsnes $\mathrm{O}$, Reikerås $\mathrm{O}$, Engesæter $L B$, Dahl $\mathrm{OE}$. The proportion of perioperative mortalities attributed to cemented implantation in hip fracture patients treated by hemiarthroplasty. Hip Int. 2014;24(4):363-8.

\section{Publisher's Note}

Springer Nature remains neutral with regard to jurisdictional claims in published maps and institutional affiliations.

Ready to submit your research? Choose BMC and benefit from:

- fast, convenient online submission

- thorough peer review by experienced researchers in your field

- rapid publication on acceptance

- support for research data, including large and complex data types

- gold Open Access which fosters wider collaboration and increased citations

- maximum visibility for your research: over $100 \mathrm{M}$ website views per year

At $\mathrm{BMC}$, research is always in progress. 